\title{
A Queer Criminal Career
}

\begin{abstract}
Since the publication of Moffitt's (1993) important research on adolescence-limited and life-coursepersistent offending, there has been a renewal of the often tacit goal of criminology of identifying the individual factors that facilitate and inhibit deviant behaviour. In focusing on early childhood biological, genetic and psychological development, and considering social environment only as a mediating factor, these approaches miss some of the queer pathways to crime. While queer criminology has done much to highlight how sexuality and gender diversity shapes victimisation, everyday offending by sexuality and gender diverse people remains opaque. We argue that examining offending by queer people inevitably destabilises takenfor-granted ideas about offending and desistance from offending. Moreover, given the increasing numbers of young people identifying as queer ${ }^{1}$, and that they are more likely to be sanctioned by criminal processing systems, we highlight the importance of exploring the experiences of queer young people. Here we suggest a critical criminological lens can queer ${ }^{2}$ (Ault 1996) notions of desistance and offending and offer up an alternative, queer criminal career, which starts not with bio-psychological dysfunctioning, but with social exclusion and criminalisation of identity. Due to the preponderance of research in the United States and United Kingdom around these issues, we draw primarily on this research to contend that social exclusion and criminalisation are key factors that collide to produce a queer criminal career. Further, we suggest that any work on these queer experiences in Australia is also likely engaging with the social exclusion and criminalisation of non-white, specifically Aboriginal and Torres Strait islander, peoples.
\end{abstract}




\section{A QUEER CRIMINAL CAREER}

\section{Introduction}

Since the publication of her important research in 1993, Moffitt's findings on the attributes of individuals persistently criminalised over their life-course has reinvigorated a tacit goal of criminologyparticularly, biocriminology-of identifying the individual factors that determine 'criminality'. With the determinants identified and 'evidenced', this type of positivism is seen by many to offer criminal justice agencies the ability to focus their resources on those who cost and harm the most: the 'life-course-persistent offender' (Moffitt 1993). The explosion of life-course and neurodevelopmental research over the last 20 years has provided some evidence of the transitory nature of rule-breaking for the majority of young people who come in contact with the criminal processing system. These young people commonly age out of behaviour that attracts police intervention by 25 when certain transition 'rituals' provide a pathway to social conformity and criminal desistance (Maruna 2001; 2011). However, for a small proportion of people (5-10\%), contact with the criminal processing system ${ }^{3}$ is persistent throughout the life-course (Moffit 1993).

Those that are subject to life-course-persistent criminalisation share a range of biological and neurodevelopmental characteristics that can present as early as 17 months (Tremblay et al. 2004) and are measurable from age three. The Dunedin study has identified under-controlled temperament, neurological abnormalities, and delayed motor development at age three, and low intellectual ability, reading difficulties, and low scores on memory and hyperactivity between age three and 13 as strong predictors of 'life-coursepersistent offending' (Moffitt \& Caspi 2001; Moffitt 2006). Research has also identified links between earlyonset violent offending and infant nervous system maldevelopment (Raine, Brenan \& Mednick, 1994; Raine et al. 1996), prenatal malnutrition and Antisocial Personality Disorder (Neugebauer, Hoek \& Susser 1999), enlarged corpus callosum, abnormal corpus callosum connective function and low levels of the enzyme monoamine oxidase $A$ and the development of antisocial behaviour at various points in the life-course (Caspi 
et al. 2002). ${ }^{4}$ These bio-psychological factors intersect with dysfunctional social and family environments, which are often connected to parental/carer mental health issues, drug misuse, and socio-economic disadvantage (Moffitt 2006). These biosocial factors are thought to interact to create the conditions for disengagement from school and the development of negative social capital such as the creation of peer groups that engage in antisocial behaviour-conditions and social formations that attract over-policing (Crowthers 2004; Dwyer 2012). Moffitt (2006) argues that neurodevelopmental issues in early childhood lead some people into life-course-persistent criminalisation processes, while social factors such as peer pressure and family breakdown in adolescence are the key factors leading to adolescence-limited criminalisation.

From a critical perspective, it is often difficult to get past the first and most significant stumbling block with Moffitt's (1993) initial framing of the problem: that crime-and thus, criminality-is socially constructed. As it is not a fixed variable, any consideration of the propensity to criminality must first account for the shifting sands of what is and is not illegal over time, and then conceptualise and operationalise variables to account for the under- and over-policing, judgment, and incarceration of some people. Already the syntax for the quantitative equation is too complex to then overlay criminal and biomedical surveillance data collected by a state that defines both crime and the allocation of criminal processing resources. Some of the most important critiques of biocriminology come from feminists, who point to the ways in which Moffitt's (1993; 2006) conceptualisation of the problem deepens the gender assumptions about criminality already embedded in criminological theory and practice (Brown 2006; Daly 2010; Chesney-Lind \& Morash 2013). To this, we add a queer critique of lifecourse and developmental criminology.

As with much experimental research reliant upon large (and in the case of Moffitt's Dunedin study, longitudinal) data sets, marginal experiences are often excluded as outliers. In these margins exists alternative criminal career pathways that may have more to do with familial, social, and institutional characteristics than the biological or neurodevelopmental factors identified by Moffitt (2006). It is these marginal experiences and queer pathways that are of most interest to our discussions here. Granted; it is likely that there are some queer career criminals who have the bio-psychological indicators of Moffitt's lifecourse-persistent offenders. However, we suggest that it is important to consider how a queer pathway to 
life-course-persistent behaviour might be wholly different to that documented by Moffitt and other lifecourse and neurodevelopmental criminologists. In these marginal narratives of criminalisation, we are offered alternative resistance and desistance strategies for those who are similarly criminalised.

The everyday social lives of queers - of school runs, bill paying, colds and flus - has remained opaque until quite recently; especially in Australia, where we are still grappling with the rights of queers to marry, adopt, and access fertility treatment. Queer lives are (in)visible lives; all too visible in laws and practices that regulate our rights to citizenship, and invisible in everyday cultural practices that embed us in the meaning of that citizenship. The logics of governmentality and claims-making requires that queers are visible enough to constitute a stakeholder in decision making, yet this visibility means that queers more easily surveilled and subject to a series of manoeuvres that reframe their queerness as part of the norm. This normalisation, however, is reserved for only those queers who are not 'too queer'; those who want to marry, not those who want to destabilise the concretised dichotomous gender order.

Social and legislative recognition of non-normative sexuality and gender enables us to consider the experiences of queers, and to begin considering the wider implications of alternative pathways through the criminal processing system. Importantly, though, this is not inclusion of our own making. Even as some gay men and lesbians are empowered by the state to marry, have or adopt children, and be recognised as nextof-kin, how these rights are articulated and implemented in policies and practices is heteronormative and cisnormative-and, we argue, a privileged global North analysis of the critical issues facing queers worldwide. Ball (2017) suggests that in addition to a noun and adjective, queer is also a transitive verb, which captures the process of destabilising, reforming, critiquing, which can "spoil the effect or success of; queer one's plans' (Merriam-Webster Online 2017). Rather than just adding queers to the mix of criminological theory and practice, Ball (2017) argues that engaging with the peculiarity of queer lives necessary means that we must queer the very foundations on which criminological knowledge is knowable.

We argue the acknowledgement of queers in the criminal processing system necessarily thwarts the heteronormative and cisnormative functioning of the criminal processing system. In effect, queer lives are so 
peculiar that we must reconsider some of the unspoken assumptions about how sexuality and gender are embedded in the criminological enterprise (Ball 2017). Rather than outliers in quantitative analyses, we suggest that the marginal experiences of queer criminal careers represent a disruption of the taken-forgranted criminal 'justice' processes. While our interest in this paper is squarely upon queers, the hypothesised role of familial exile and the consequential survival crimes is a pathway shared by others who are without the necessary familial and social resources to resist crime and circumvent criminalisation processes.

\section{Queers and Criminality}

Building on earlier research (Mason 2002, Tomsen 2009), the last five years has seen a growing scholarship in an area that has come to be known as 'queer criminology'. While most attention has been on queer people as victims, queer criminologists have also begun to examine the unique characteristics of queer offending. Recognition by criminal justice agencies (and criminology more generally) has been critical in making some in-roads into the barriers faced by queer offenders. However, this recognition of sexuality and gender diversity (in law and practice) necessarily causes disruptions to normalised conceptions of criminality and justice, including those embedded in biocriminology. For many, their queer criminal career is initiated by familial and cultural forces beyond their control-such as family exile due to heterosexism and cissexismand sustained through the normal adolescent-limited boundary testing and into a life-course of being subject to criminalisation.

Importantly, our intent in this commentary is to problematise the biological assumptions of criminal career research by considering the impact of sexuality and gender on our understandings of criminal injustice. However, this is but one intersection informing these complex lives. Queers do not come in one white, middle-class, ableist package, and as with others similarly criminalised, queer career criminals are likely to experience criminal injustice through the multiple intersections of class, race, (dis)ability, gender and sexuality. While some criminal career research has considered the sex differences in life-course-persistent criminalisation (Benda 2005; Mazerolle et al. 2000; Moffitt \& Caspi 2001), our survey of the field has 
identified that the impact of sexuality and gender identity has yet to be considered by developmental and life-course criminology. The existing research has also ignored how marginalisation experienced by queers undermines the efficacy of traditional desistance models (Graham 2016; Laub \& Sampson 2001), especially for young people in contact with the criminal processing system whose lives are marked by family exile. As identified in the criminal career (Moffit 1993; 2006) and desistance (Graham 2016) research, reduced familial and social capital are critical to the onset and entrenchment behaviours deemed criminal, which unless addressed, could be inhibitors to desistance across the lifecourse.

Demographic attributes for sexuality are becoming more commonplace in criminological research (Jenness 2010) and awareness about some of the experiences of gay men and lesbians have now been documented in mainstream research (Butler et al. 2010). However, as the Australian census (and the US census) is yet to ask about sexuality, it is difficult to talk of prevalence in the population or in the criminal processing system. Additionally, while gay men and lesbians are more commonly considered in criminological research, this is not the case for the other queers, such as those who identify as transgender, gender nonconforming, bisexual, asexual, or pansexual. Queer offenders' experiences are rarely considered or are often excluded on methodological grounds. Definitional concerns also make identifying these sub-populations in prisons difficult as they may not identify whilst detained or incarcerated given the safety issues documented in the literature (Jenness 2010; Robinson 2011; Simpson et al. 2016; Wilson et al. 2016).

The most significant problem in identifying the number and proportion of queers entering the system is the absence of demographic intake data relating to sexuality and gender at most points in the criminal processing system (Robinson 2011). Despite constituting a relatively small proportion of prisoners, transgender people are more likely to come to the attention of criminal processing and corrective services. This is because their gender identity can be documented on intake when they request housing appropriate to their gender-if their gender clashes with the sex markers on their identity documents-or by prison officers in risk assessment (Sumner \& Jenness 2013; Jenness 2010; Robinson 2011; Scott 2013). ${ }^{5}$ Even so, we still have no precise Australian data on how many queers are detained by police, subject to court proceedings, incarceration, or community sentences. These issues are made more complex in the context of young 
people's offending given the sensitivities and risks around disclosure of sexuality and gender identity in carceral settings.

The only Australian study to have collected reliable population data on queer prisoners is the Sexual Health and Attitudes of Australian Prisoners (SHAAP) study (Richters et al. 2008). In brief, for each New South Wales (NSW) and Queensland prison (except for remote and isolated settings like work camps) a random sample was drawn from a list of all current prisoners. Of those invited to participate, 2,351 men and women were interviewed (participation rate, $80 \%$ ). Of these, 37 per cent of female prisoners identified as lesbian or bisexual (vs. 3.4\% in the community), 5 per cent of male prisoners identified as gay or bisexual (vs. $3.2 \%$ in the community), and 0.3 per cent transgender or sister-girl (Butler et al. 2010; Richters et al. 2008; Richters et al. 2014). ${ }^{6}$ With 38,845 adult prisoners housed in Australia $(35,745$ in men's prisons and 3,094 in women's prisons; ABS 2016), the above estimates imply approximately 2,932 lesbian, gay and bisexual, and 117 transgender prisoners in Australian prisons. If we account for prison 'throughput" ${ }^{7}$ these figures would be significantly higher. Nearly one in three of lesbian or bisexual female prisoners is estimated to be Indigenous, and one in five gay or bisexual male prisoners is Indigenous (Butler et al. 2010), thus highlighting that any work on the over-incarceration of queers in Australia is also about the over-incarceration of Aboriginal and Torres Strait islander peoples.

International research shows that young queer populations are particularly at risk of imprisonment, with United States' (US) studies consistently finding higher rates of imprisonment for queer offenders (Belknap et al. 2013; Curtin 2002; Richie 2014). Belknap et al. (2013) found that 13.4 per cent of young people sampled from Ohio juvenile detention facilities identified as lesbian, gay or bisexual ( $27 \%$ of girls and $5 \%$ of boys). Of juvenile offenders surveyed in six US juvenile justice jurisdictions, Irvine (2010) found 15 per cent identified as lesbian, gay bisexual or transgender, gender non-conforming ${ }^{8}$, or questioning their sexuality ( $11 \%$ of boys $\& 27 \%$ of girls). Six per cent of Irvine's participants identified as transgender or gender nonconforming (Irvine 2010). In an Australian context where increasing numbers of young people are being detained and remanded in some states (AlHW 2015)-and increasing numbers of young people are 
identifying as LGBTIQA+ (Hillier et al. 2010; Robinson et al. 2014)-there is a pressing need to understand queer young people's experiences of these settings.

\section{Queering Criminal Careers}

The over-representation of queers in the criminal processing system can be attributed to two distinct processes: social exclusion due to sexuality and gender identity; and criminalisation processes in terms of the construction and application of cisnormative and heteronormative laws and criminal justice practices. Social exclusion as mediated by structural inequalities is a significant factor in understanding the queer criminal career. Abuse, harassment, discrimination and its antecedents (such as homelessness, alcohol and other drug misuse, and mental health issues) re-instantiate queers on the margins of society (Hunt, J \& Moodie-Mills 2012; Irvine 2010; Grant et al. 2011; Hillier et al. 2010; Mays \& Cochran 2001; Perkins et al. 1994; Prestage et al. 2007). While this marginality could arguably lead to resilience for some, it is nonetheless important to understand how marginality impacts on the production and trajectory of queer criminal careers, and how this marginality may facilitate criminalised queer subjects. Furthermore, it is increasingly important to explore the experiences of queer young people specifically given that more young people are now identifying as queer in some way (Hillier et al. 2010, Robinson et al. 2014) and research from the US suggests they are more often subject to schooling and criminal justice sanctions (Himmelstein and Bruckner 2011). Such marginality may be expressed and informed by the inter-related issues of criminalisation of identity, family exile and homelessness, and barriers to employment.

\section{Criminalisation of Sexuality and Gender Identity}

Sexuality and gender diverse people have a long history of estranged, violent, and problematic relationships with criminal processing systems as both victims and offenders (Dwyer 2012; Asquith 2012). Young queer people experience criminalisation for same-sex sexual behaviour (Dwyer 2014; Curtin 2002; Hunt \& Moodie-Mills 2012), especially those queer people residing in states where an uneven age of consent has applied to same sex relationships (Dwyer 2011; Dennis 2013). Queers have been subject to over-policing 
in the night time economy (Dwyer 2012; Dwyer \& Ball 2009), with gay men criminalised for their use of public spaces (such as beats) (Dalton 2008), and all queers over-policed in quasi-private spaces (such as using 'sniffer dogs' in LGBTQ nightclubs; Dwyer 2011) and police raids on LGBTQ identified nightclubs, like the raid on the Tasty nightclub in Melbourne in 1994 (Russell 2015).

Transgender people experience differential treatment from police without cause (Dwyer 2012; James et al. 2016), with US research showing some trans women are arrested for simply having identification that mismatches their appearance (Sylvia Rivera Law Project 2007). James et al. (2016) found that of the 27,715 respondents to the US Transgender Survey, two per cent had been arrested in the previous year, and that 22 per cent of these respondents believed they were arrested because they were transgender. Another example of differential treatment relates to US police targeting and searching trans women and sex workers for condoms as evidence of engaging in "prostitution-related offenses", and the use of condoms as evidence of "prostitution-related offenses" in criminal proceedings (Wurth et al. 2013). Similarly, the distribution of black market hormones is another crime impacting trans people (Sylvia Rivera Law Project 2007). When hormones are refused to trans men and trans women by medical practitioners, or legal access to hormones is too expensive, black market hormones can often be the only option to maintain their gender identity. All these factors highlight the importance of documenting in detail how young queer people come to be involved in queer criminal careers (Rogers, Asquith \& Dwyer 2017).

In each of these examples, it is the exceptional characteristics or behaviours of an individual's gender identity, sexual behaviour, or sexuality that is criminalised. What research does exist on queer offending focuses on the sex, gender, and sexuality-related offences experienced differentially by queer offenders (such as the criminalisation of sodomy, differential ages of consent, policing of beats, unprotected sex, and paedophilia) (Ball 2017). In this sense, queer offending is exceptionalised and festishised in and by the criminal processing system. Queer people are subject to laws that their heteronormative peers are not, and it is important to document the ways in which heteronormative and cisnormative laws constructed the queer body as criminal. However, with few exceptions (such as Panfil's (2017) ground-breaking work on queer gang 
members), we know little of how sexuality and gender diversity shapes everyday offending and is subject to everyday criminalisation.

Family exile and homelessness

A central characteristic of queer criminalisation is the experience of homelessness, often produced by family exile after coming out (Abramovich 2012; Valentine et al. 2003). Exiled lesbian, gay, and bisexual youth experience higher rates of homelessness that can lead to 'survival crimes' such as property theft and selling drugs, and other criminalised economies such as unregulated sex work (Irvine \& Canfield 2015/6). In Australia, people who identify as LGB were twice as likely to experience homelessness than their heterosexual counterparts (McNair et al. 2017), and in the US, gay, lesbian, and transgender youth make up 40 per cent of the young homeless population despite making up only 5-7 per cent of young people (Hunt \& Moodie-Mills 2012). This brings queers into contact with the criminal processing system at higher rates than their heterosexual and cisgender ${ }^{9}$ peers (Curtin 2002; Richie 2014; Hunt \& Moodie-Mills 2012; Irvine 2010). Homeless transgender people are 2-2.5 times more likely to be incarcerated (Grant et al. 2011; James et al. 2016) and are incarcerated for minor homelessness-related offences, such as loitering or sleeping outside (Sylvia Rivera Law Project 2007).

Homelessness is common across queer communities, which suggests a critical absence of protective factors against the onset of criminal behaviour and a critical support network to enhance desistance. The social structures assumed to exist for others (such as stable family and secure housing), and used to help them desist from crime and avoid criminalisation, may be absent for many queers. For instance, service providers interviewed by McNair et al. (2017) noted family conflict and rejection as key reasons for LGBTQ homelessness, and reasons why LGBTQ people were leaving home at a younger age than their peers. Oparah (2012) also notes these issues as a core reason why transgender young people run away or are exiled from family homes in the US. Meiners (2007), in examining the history of sex offender registries in the United States, argues how the construction of 'stranger danger' within sexual violence prevention discourse (at sites such as the school) work to legitimise and reaffirm the myth that the heteronormative nuclear family is a site 
of safety and protection-a myth only sustained if we overlook how gender and sexuality plays out in such heteronormative/heteropatriarchal social formations (Irvine \& Canfield 2015/6).

In addition to highlighting the queer factors that trigger the onset of criminalised behaviour (such as family exile), queer criminal careers also highlight the heteronormative assumptions underlying some desistance theory and practices (such as a family or community that accepts and embraces sexuality and gender diversity). While families-of-choice may mediate and buffer queers' experiences of exile from families-of-origin, the scant existing research on these alternative family forms means that it is difficult to assess whether strengthening families-of-choice will ameliorate the harms caused, and trajectories initiated, by the original exile from family-of-origin (Dewaele 2016).

\section{Employment barriers}

Queers experience high rates of unemployment and employment discrimination (Asquith 1999; Drydakis 2014; Tilcsik 2011; Willis 2009). In the Australian context, Barrett, Lewis, and Dwyer (2011, p. 9) found that queer workers were disclosing their sexuality and gender diversity more often, but they experienced more discrimination at work as a result, including "death threats (80\%), threats of physical abuse via telephone $(67 \%)$, property damage $(33 \%)$, verbal threats of sexual abuse $(30 \%)$, verbal threats of physical abuse $(29 \%)$ and verbal threats of sexual abuse via telephone (25\%)". The International Gay and Lesbian Association (2014) found that at least 20 per cent of European lesbians and gay men had experienced discrimination, and that 31-49 per cent were closeted at work due to fear of discrimination (IGLA 2014; James et al. 2016). James et al. (2016) found that transgender people were three times more likely than their US peers to be unemployed, and twice as likely to be living in poverty. Additionally, 15 per cent of respondents who had employment were verbally harassed, physically attacked, and/or sexually assaulted, and 23 per cent had experienced forms of workplace discrimination because of their transgender status, and 15 per cent had resigned due to discrimination or violence (James et al. 2016).

Employment insecurity such as this can lead some queers into the 'underground economies' (James et al. 2016) of illicit drug selling and street-based sex work, which in many jurisdictions remains criminalised. 
These economies attract high police surveillance and intervention (Scott 2013; Sylvia Rivera Law Project 2007). Irvine's (2010) study of 2100 lesbian, gay, bisexual, questioning, and gender non-conforming young people in juvenile detention found there were significant proportional differences in sex work employment between heterosexual boys (1\%) and girls (5\%) and lesbian, gay, bisexual and queer boys (10\%) and girls (11\%). At least 11 per cent of transgender people had engaged in sex work (Grant et al. 2011; James et al. 2016), which contrasts substantially with the Prostitutes' Education Network's estimation of only one per cent of cisgender women (Grant et al. 2011). Further, Garofalo et al. found 76 per cent of trans women engaging in sex work had been arrested and 37 per cent had been incarcerated (Garofalo et al. 2006). Importantly, the over-representation of queers cannot be solely attributed to negative life choices stemming from social exclusion such as family exile. The term 'survival crime' is only relevant in those jurisdictions where sex work remains criminalised. We argue that in those jurisdictions where sex work is decriminalised and regulated, the decision to engage in this work could be considered strategic given the level of autonomy and lack of employment barriers. As legal employment is a key protective and desistance factor, we need to understand how criminalised and unregulated work impacts on the development of queer criminal careers.

\section{Queering criminal career research}

A critical outcome in the development of criminal career research has been the identification of transitional and developmental points between childhood, adolescence, and adulthood that facilitate the decision to (dis)engage in behaviour deemed criminal. DeLisi and Piquero (2011) have identified the lack of methodological and sampling diversity within existing life-course criminology, and recommend the expansion of the field to address the critique-largely from critical realist, radical, feminist and critical criminologists ${ }^{10}-$ that research to date has not deployed qualitative approaches to understand typologies of career offending, or fully considered the 'cardinal demographic' of sex, and the situational contexts of offending. They also advise that biosocial approaches will continue to elicit a 'so what?' critique until such time that they can identify the critical, modifiable early-life factors that shape decisions in relation to criminality (DeLisi \& Piquero 2011), such as family dysfunction and family exile. 
As critical criminologists, we suggest that in the disruptions to statistical models, we may find narratives that tell us more about the familial, social, and institutional contexts of resistance, persistence, and desistance. In adopting alternative methodologies (such as appreciative enquiry and life-course mapping), critical criminologies such as queer criminology may offer a new model for understanding the key developmental and social factors that produce and influence queer criminalisation, especially in relation to the developmental contexts that have been shown as instrumental in offending patterns of career criminals, such as social capital and family exile. For example, Ryan et al. (2009) found family rejection was a significant predictor of a range of negative outcomes including increased likelihood of attempted suicide (84\%), depression (59\%), and use of illegal drugs (34\%). In the context of queer criminal careers, where exile from family is possible and social exclusion is probable, traditional desistance strategies may simply miss the mark for queer young offenders, especially when these young people are often excluded not only from family but also from peer and schooling networks.

Another gap in the career criminal research is the critical adult factors that enhance desistance such as marriage, employment, and parenthood (DeLisi \& Piquero 2011). In each of these areas, queer people are likely to have a differential experience from those documented in conventional career criminal research. In DeLisi and Piquero's (2011) meta-analysis of criminal career research, they found that 'one of the most important life events contributing to desistance is marriage'. Given, at the time of writing, Australia's failure to enact the right to marry for same sex couples, this important desistance ritual is unavailable to queer offenders in this country. Programs and policies that do not account for these differences will undermine attempts at desistance from queer criminal careers.

It is also important to acknowledge that even if marriage was a legal option for those in same-sex relationships, such a legal investment to equality can work at re-instantiating social exclusion for many queers. For those whose identities, intimate relationships, and families are not binary, monogamous and/or nuclear, respectively, can be rendered 'abject, unworthy, or unable to be assimilated into either hetero- or homonormative citizenship' (Agathangelou et al. 2008 cited in Quinn \& Meiners 2013, p 166). This logic suggests that some queer people are worthy of state recognition and support while others are deemed 
unworthy, and thus contributing to the very factors that can lead to being subject to criminalisation (Quinn \& Meiners 2013).

It is also important to understand the impact of these human rights deficiencies in Australian policies and practices (Richards \& Dwyer 2014), and consider how restrictions imposed on queer peoples' social citizenship (through limitations on recognition of same-sex relationships and rights to adopt) may also shape their experience of incarceration (such as conjugal rights for ACT and Victorian offenders, and access visits from non-biological children) (Indig et al. 2009; Wiggum 2008-9; Wolfe 2008). In addition to heterosexist attitudes and violence from criminal processing staff, the lack of awareness and acknowledgement of queers in police detention, prisons, and on community sentences can mean that rehabilitation, education, and support programs may exclude their needs (Belknap et al. 2013; Curtin 2002; Richie 2014; Dennis 2013; Irvine 2010).

\section{Conclusion}

The queer criminal career is an alternative pathway into and out of crime. Researchers and practitioners working on the development of desistance programs are unlikely to identify the ways that hetero- and cisnormative assumptions can inhibit desistance for queer career criminals unless they consider the experiences of queers transitioning through the criminal processing system. Further, offender support programs that assume that 'pro-social' is a neutral concept may not understand the significant ways in which heteronormative and cisnormative ideals shape Australian social citizenship. Focusing on the exceptional experiences of queer offenders is important in the short term if we are to develop appropriate resistance and desistance strategies. Understanding the trajectories of the queer criminal career and the queer pathways to desistance can provide new knowledge about others who share the criminalisation of identity, family exile, social exclusion, and partial social citizenship. This laudable short-term goal of making life just a little easier for queer career criminals, however, must be matched with the longer term goals of displacing the criminalisation of sexuality and gender, and given that "their laws will never make us safer" (Spade 2013), disrupting the carceral enterprise unpinning criminology. In this respect, the criminological enterprise as a whole-but especially, life-course and developmental criminology-could benefit from a queer lens. 


\section{References}

Abramovich, IA 2012, 'No safe place to go', Canadian Journal of Family \& Youth, vol. 4, no. 1, pp. $29-51$.

Ault, A 1996, 'The dilemma of identity: bi women's negotiations', in S Seidman (ed.) Queer theory/sociology, Blackwell Publishers, Cambridge.

Australian Bureau of Statistics 2016, Prisoners in Australia 2016, no.4517.0, ABS, Canberra.

Australian Institute of Health \& Welfare 2015, 'Youth detention population in Australian 2015', Bulletin 131, viewed 6 October 2017, www.aihw.gov.au/getmedia/c24d5548-c10e-4ce4-b8b3-b6414a8f3bfb/ 19489_1.pdf.aspx?inline=true.

Asquith, NL 2012, 'Vulnerability and the art of complaint making' in I Bartkowiak-Théron \& NL Asquith (eds.), Policing vulnerability, Federation Press, Crow's Nest, NSW.

Asquith, NL 1999, 'Sexuality at work', New Zealand Journal of Industrial Relations, vol. 24, no. 1, pp. 1-24.

Ball, M 2016, Criminology \& queer theory: Dangerous bedfellow?, Palgrave, London.

Barrett, N, Lewis, J and Dwyer, A 2011, 'Effects of disclosure of sexual identity at work for gay, lesbian, bisexual, transgender and intersex (GLBTI) employees in Queensland, in Proceedings of the 25th Annual Australian and New Zealand Academy of Management Conference, Australian and New Zealand Academy of Management (ANZAM), Amora Hotel, Wellington.

Belknap, J 1996, The invisible woman: gender, crime, and justice, Wadsworth, Belmont, CA.

Belknap, J, Holsinger, K \& Little JS 2013, 'Lesbian, gay and bisexual youth incarcerated in delinquent facilities' in D Peterson \& VR Panfil (eds.), Handbook of LGBT Communities, Crime, and Justice. Springer, London \& New York.

Benda, BB 2005, 'Gender Differences in Life-Course Theory of Recidivism: A Survival Analysis', International Journal of Offender Therapy and Comparative Criminology, vol. 49, no. 3, pp. 325-42.

Brown, M 2006 'Gender, Ethnicity, and Offending over the Life Course: Women's Pathways to Prison in the Aloha State', Critical Criminology, vol. 14, no. 2, pp. 137-58.

Burt, CH \& Simons, RL 2014, 'Pulling back the curtain on heritability studies: Biosocial criminology in the postgenomic era', Criminology, vol. 52, no. 1, pp. 223-62.

Butler, JP 1990, Gender Trouble: Feminism and the Subversion of Identity, Routledge, New York.

Butler, T, Richters, J, Yap, L, Papanastasiou, C, Richards, A, Schneider, K, Grant, L, Smith, A \& Donovan, B 2010, Sexual health and behaviour of Queensland prisoners: Queensland and New South Wales comparisons, National Drug Research Institute, Curtin University \& Public Health \& Community Medicine, UNSW, Perth \& Sydney.

Carrier, N \& Walby, K 2015, 'Is biososcial criminology a predisposition not to learn from the social sciences?', Journal of Theoretical \& Philosophical Criminology, vol. 7, no. 1, pp. 96-108.

Caspi A, McClay J, Moffitt TE, Mill J, Martin J, Craig IW, et al. 2002, 'Role of Genotype in the Cycle of Violence in Maltreated Children, Science, vol. 297, pp. 851-54.

Costell M \& Nannup R 1999, Report of the National Indigenous Sistergirl Forum. Australian Federation of AIDS Organisations, Sydney.

Crowthers, C 2004, 'Over-policing and under-policing social exclusion' in RH Burke (ed.), Hard cop, soft cop: dilemmas and debates in contemporary policing. Routledge, London \& New York.

Curtin, M 2002, 'Lesbian \& bisexual girls in the juvenile justice system', Child \& Adolescent Social Work Journal, vol. 19, no. 4, pp. 285-301.

Dalton, D 2008, 'Gay Male Resistance in 'Beat' Spaces in Australia: A Study of Outlaw Desire', Australian Feminist Law Journal, vol. 28, no. 1, pp. 97-119. 
Daly, K 2010, Feminist perspectives in criminology: a review with gen $\mathrm{Y}$ in mind', in T Newburn \& T Jefferson (eds.), The SAGE Handbook of Criminological Theory, SAGE, London \& Thousand Oaks.

DeLisi, M \& Piquero, AR 2011, 'New Frontiers in Criminal Careers Research, 2000-2011: A State-of-the-Art Review, Journal of Criminal Justice, vol. 39, no. 4, pp. 289-301.

Dennis, JP 2013, 'The LGBT Offender' in D Peterson \& VR Panfil (eds.), Handbook of LGBT Communities, Crime, and Justice, Springer, London \& New York.

Draper, MR, Olsen, JM, McGraw, J \& Sturtevant, D 2015, An interpretivist introduction to the biocriminology and critical criminology debate, Journal of Theoretical and Philosophical Criminology, vol. 7, pp. 42-60.

Drydakis, N 2014, 'Sexual orientation and labor market outcomes', IZA World of Labor, no. 111, viewed, 29 September 2017, www.prideinclusionprograms.com.au/content/uploads/2015/06/sexualorientation-and-labor-market-outcomes-1.pdf

Dwyer, A 2011, 'Policing LGBT young people as a research gap', Current Issues in Criminal Justice, vol. 22, no. 3, pp. 415-33.

Dwyer, A 2014, “'We're not like these weird feather boa-covered AIDS-spreading monsters": How LGBT young people and service providers think riskiness informs LGBT youth-police interactions', Critical Criminology, vol. 22, no.1, pp. 65-79.

Dwyer, A 2012, 'Policing visible sexual/gender diversity as a program of governance', International Journal of Crime and Justice, vol. 1, no.1, pp. 14-26.

Dwyer A \& Ball, M 2009, 'Policing sexualities', in RG Broadhurst \& SE Davies (eds.), Policing in context: introduction to police work in Australia. Oxford University Press, South Melbourne.

Garofalo, R, Osmer, E, Doll, M, Harper, GW \& Deleon, J 2006, 'Overlooked, misunderstood \& at-risk: exploring the lives and HIV risk of ethnic minority male-to-female transgender youth, Journal of Adolescent Health, vol. 38, no. 3, pp. 230-6.

Graham H 2016, Rehabilitation work: supporting desistance and recovery, Routledge, London \& New York.

Grant, JM, Mottet, LA, Tanis, J, Harrison, J, Herman, JL \& Keisling, M 2011, Injustice at every turn: a report of the national transgender discrimination survey, National Center for Transgender Equality, Washington.

Hillier, L, Jones, T, Monagle, M, Overton, N, Gahan, L, Blackman, J \& Mitchell, A 2010, Writing themselves in 3: the third national study on the sexual health and wellbeing of same sex attracted and gender questioning young people. Australian Research Centre in Sex, Health \& Society, La Trobe University, Melbourne.

Himmelstein, KEW and Bruckner, H 2011, Criminal justice and school sanctions against non-heterosexual youth: a national longitudinal study, Pediatrics, 127(1), 49-57.

Hodge, D 2015, Colouring the rainbow: blak queer and trans perspectives, Wakefield Press, Adelaide.

Hunt, J \& Moodie-Mills, A 2012, The unfair criminalization of gay and transgender youth, Center for American Progress, Washington.

Indig, D, Topp, L, Ross, B, Mamoon, H, Border, B, Kumar, S \& McNamara, M 2009, 2009 Health inmate survey: key findings report, Justice Health, Sydney.

International Lesbian, Gay, Bisexual, Trans \& Intersex Association (ILGA)-Europe 2016, Annual review of the human rights situation of lesbian, gay, bisexual, trans and intersex people in Europe, IGLA, Belgium.

Irvine, A 2010, "We've had three of them": addressing the invisibility of lesbian, gay, bisexual, and gender nonconforming youths in the juvenile justice system', Columbia Journal of Gender and Law, vol. 19, no. 3, pp. 675-701. 
Irvine, A \& Canfield, A 2015/6, 'The overrepresentation of lesbian, gay, bisexual, questioning, gender nonconforming and transgender youth within the child welfare to juvenile justice crossover population', American University Journal of Gender, Social Policy \& the Law, vol. 24, pp. 243-61.

James, SE, Herman, JL, Rankin, S, Keisling, M, Mottet, L \& Anafi, M 2016, The report of the 2015 U.S. transgender survey. National Center for Transgender Equality, Washington.

Jenness, V 2010, 'From Policy to Prisoners to People: A 'Soft Mixed Methods' Approach to Studying Transgender Prisoners, Journal of Contemporary Ethnography, vol. 39, no. 5, pp. 517-53.

Laub, JH \& Sampson, RJ 2001, 'Understanding desistance from crime, in M Tonry (ed.), Crime and justice: a review of research, University of Chicago Press, Chicago.

Mangels, NJ 2000, 'Latent biases in biocriminological research', The Justice Professional, vol. 13, no. 2, pp. 105-23.

Maruna, S 2011, 'Reentry as a rite of passage', Punishment \& Society, vol. 13, no. 1, pp. 3-28.

Maruna, S 2001, Making good: how ex-convicts reform and rebuild their lives, American Psychological Association Books, London \& Washington, DC.

Mason, G 2002, The spectacle of violence: homophobia, gender and knowledge, London, Routledge.

Mays, VM \& Cochran, SD 2001, 'Mental health correlates of perceived discrimination among lesbian, gay, and bisexual adults in the United States', American Journal of Public Health, vol. 91, no. 11, pp. 186976.

Mazerolle, P, Brame, R, Paternoster, R, Piquero, S, Dean, C 2000, 'Onset age, persistence, and offending versatility: comparisons across gender', Criminology, vol. 38, no. 34, pp. 1143-72.

McNair, R, Andrews, C, Parkinson, S and Dempsey, D 2017, LGBTQ homelessness: risks, resilience, and access to services in Victoria. GALFA, Sydney.

Merriam-Webster Online 2017, 'Queer', viewed 28 September 2017, www.merriamwebster.com/dictionary/queer, 1 October 2017.

Moffitt, T 1993, 'Adolescence-limited and life-course-persistent antisocial behavior: a developmental taxonomy', Psychological Review, vol. 100, no. 4, pp. 674-701.

Moffitt, TE 2006, 'Life-course-persistent versus adolescence-limited antisocial behavior', in D Cicchetti \& DJ Cohen (eds.), Developmental psychopathology: risk, disorder, and adaptation, vol. 3, Wiley, New York.

Moffitt, TE \& Caspi, A 2001, 'Childhood predictors of differentiate life-course persistent and adolescencelimited pathways, among males and females', Development and Psychopathology, vol. 8, pp. 399424.

Chesney-Lind, M \& Morash, M 2013 'Transformative feminist criminology: a critical re-thinking of a discipline', Critical Criminology, vol. 21, no. 3, pp. 287-304.

Neugebauer, R, Hoek, HW, Susser, E 1999, 'Prenatal exposure to wartime famine and development of antisocial personality disorder in early adulthood', Journal of the American Medical Association, vol. 281, pp. 455-62.

Oparah, JC 2012, 'Feminism and the (trans)gender entrapment of gender nonconforming prisoners', UCLA Women's Law Journal, vol. 8, no. 2, pp. 239-71.

Panfil, VR 2017, The gang's all queer: the lives of gay gang members, NYU Press, New York.

Perkins, R, Griffin, A \& Jakobsen, J 1994, Transgender lifestyles and HIV/AIDS risk: national transgender HIV/AIDS needs assessment project. UNSW, Sydney. 
Prestage, G, Degenhardt, L, Jin, F, Grulich, A, Imrie, J, Kaldor, J \& Kippax, S 2007, 'Predictors of frequent use of amphetamine type stimulants among HIV-negative gay men', Drug \& Alcohol Dependence, vol. 91, no. 2-3, pp. 260-68.

Quinn, T \& Meiners, ER 2013, 'From anti-bullying laws and gay marriages to queer worlds and just futures', QED: A Journal in GLBTQ Worldmaking, vol. 1, no. 1, pp. 149-75.

Raine, A., Brennan, P. \& Mednick, SA 1994, 'Birth complications combined with early maternal rejection at age 1 year predispose to violent crime at age 18 years', Archives of General Psychiatry, vol. 51, pp. 984-88.

Raine, A., Brennan, P., Mednick, B., et al. 1996, 'High rates of violence, crime, academic problems and behavioural problems in males with both early neuromotor deficits and unstable family environments', Archives of General Psychiatry, vol. 53, pp. 544-49.

Richards, K and Dwyer, A 2014, 'Unspeakably present: the (un)acknowledgement of diverse sexuality and gender human rights in Australian youth justice systems, Australian Journal of Human Rights, vol. 20, no. 2, pp. 63-79.

Richie, B 2014, 'Queering anti-prison work: African-American lesbians in the juvenile justice system' in J Sudbury (ed.), Global lockdown: race, gender, and the prison-industrial complex, Routledge, London \& New York.

Richters, J, Butler, T, Yap, L, Kirkwood, K, Grant, L, Smith, A, Schneider, K \& Donovan, B 2008, Sexual health and behaviour of New South Wales prisoners. Public Health and Community Medicine, UNSW, Sydney.

Robinson, RK 2011, 'Masculinity as Prison', California Law Review, vol. 99, no. 1, pp. 1309-1408.

Robinson, KH, Bansel, P, Denson, N, Ovenden, G, and Davies, C 2014, Growing up queer: issues facing young Australians who are gender variant and sexuality diverse, Young \& Well Cooperative Research Centre, Melbourne.

Rodgers, J, Asquith NL \& Dwyer, A 2017, 'Cisnormativity, criminalisation, vulnerability: transgender people in prisons', TILES Briefing Paper, no. 12, pp. 1-12.

Russell, E 2015, 'Revisiting the Tasty raid: lesbian and gay respectability and police legitimacy', Australian Feminist Law Journal, vol. 41, no. 1, pp. 121-40.

Ryan, C, Huebner, D, Diaz, R \& Sanchez, J 2009, 'Family rejection as a predictor of negative health outcomes in white and Latino lesbian, gay, and bisexual young adults, Pediatrics, vol. 123, no. 1, pp. 346-52.

Scheingold, SA 1984, The politics of law and order, Longman, New York.

Scott, S 2013, "'One is not born, but becomes a woman": A 14th amendment argument in support of housing male-to-female transgender inmates', University of Pennsylvania Journal of Constitutional Law, vol. 15, no. 4, pp. 1259-98.

Simpon, PL, Reekie, J, Butler, TG, Richters, J, Yap, L, Grant, L, Richards, A \& Donovan, B 2016, 'Factors associated with sexual coercion in a representative sample of men in Australian prisoners', Archives of Sexual Behaviour, vol. 45, no. 5, pp. 1195-1205.

Sumner, J \& Jenness, V 2013, 'Gender integration in sex-segregated US prisons', in D Peterson \& VR Panfil (eds.), Handbook of LGBT communities, crime, and justice, Springer, London \& New York.

Sylvia Rivera Law Project 2007, "It's war in here": A report on the treatment of transgender and intersex people in New York State men's prisons, SRLP, New York, viewed 16 July 2016, http://archive.srlp.org/resources/pubs/warinhere

Tilcsik, A 2011, 'Pride and prejudice: employment discrimination against openly gay men in the United States', American Journal of Sociology, vol. 117, no. 2, pp. 586-626.

Tomsen, S 2009, Violence, prejudice and sexuality, Routledge, New York. 
Valentine, G, Skelton, T \& Butler, R 2003, 'Coming out and outcomes: negotiating lesbian and gay identities with, and in, the family', Environment and Planning D: Society and Space, vol. 21, pp. 479-99.

Walby, K \& Carrier, N 2010, 'The rise of biocriminology: capturing observable bodily economies of "criminal man"', Criminology \& Criminal Justice, vol. 10, no. 3, pp. 261-85.

Wiggum, KE 2008-9, 'Defining family in American prisons', Women's Rights Law Reporter, vol. 30, no. 2, pp. 357-424.

Willis, P 2009, 'From exclusion to inclusion: young queer workers' negotiations of sexually exclusive and inclusive spaces in Australian workplaces, Journal of Youth Studies, vol. 12, no. 6, pp. 629-51.

Wilson, M, Simpson, PL, Butler, TG, Richters, J \& Yap, L 2016, “'You're a woman, a convenience, a cat, a poof, a thing, an idiot": transgender women negotiating sexual experiences in men's prisons in Australia', Sexualities, vol. 20, no. 3, pp. 380-402.

Wolfe, Z 2008, 'Gay and lesbian prisoners: recent developments and a call for more research', Prison Legal News, 1 October, viewed 27 November 2014, www.prisonlegalnews.org/news/2008/oct/15/gay-andlesbian-prisoners-recent-developments-and-a-call-for-more-research/

Wurth, MH, Schleifer, R, McLemore, M, Todrys, KW \& Amon, JJ 2013, 'Condoms as evidence of prostitution in the united states and the criminalization of sex work', Journal of the International AIDS Society, vol. 16, no. 1, pp. 1-3.

Young, J 1986, 'The failure of criminology: The need for a radical realism', in R Matthews \& J Young (eds.), Confronting crime, SAGE, London.

1 'Queer' is used throughout this paper as an umbrella term for those whose sex, sexuality, and/or gender is nonnormative. The alphabet soup of sex, sexuality and gender diversity is now at 14 letters (LGBTIQQAPGNCGQ), and as an acronym, it no longer serves its original purpose. Despite the significant concerns with the term 'queer', debated elsewhere, it serves our purposes in this commentary. Importantly, in this paper we do not consider the experiences of intersex people, whose experiences of crime and the criminal processing system are wholly different than those who are sexuality and gender diverse.

2 The term queer is used in two ways in this paper; first, as a noun and adjective to name and describe people who identify as sexuality and/or gender diverse; and secondly as a verb to denote 'anyone whose proclivities, practices, or sympathies defy the strictures of the dominant [heteronormative] sex/gender/sexual identity system' (Ault 1996, p. 322).

3 As with elsewhere in our work, we use this term - criminal processing system - to reflect, as others have done (Belknap 1996; Sheingold 1984), on the fact that as there is little justice in the 'criminal justice system' especially for sexuality and gender diverse people.

$4 \quad$ See Moffitt 2006 for an overview of this neurodevelopmental research

5 Segregated housing or isolation and "trans pods" have been variously used in Australia and the US to manage the safety of transgender prisoners. The former cloaks punishment as security, while research on the latter has indicated that violence from staff increases in these 'safe spaces' (Sylvia Rivera Law Project 2007). The term 'sistergirls' typically refers to Australian Aboriginal and Torres Strait Islander persons assigned at birth as male but who identify as or live as women. In traditional communities the word 'sistergirl' can also include sisters or gay men (Costell \& Nannup 1999). For a discussion of recent sistergirl experiences, see Hodge (2015). 'Throughput' refers to the number of people who enter and exit the prison system over a period of time, and will exceed the average number of people in prison measured on any given day. For Australian estimates of throughput see Avery \& Kinner 2015). 'Gender non-conforming' refers to people whose gender expression diverges from the norms expected for their gender, but still identify with the sex they were designated at birth (Irvine 2010).

$9 \quad$ Cisgender is the opposite to transgender, and denotes those women who identify with their sex at birth.

10 See for example, Burt \& Simons (2014), Carrier \& Walby (2015), Draper et al. (2015), Mangels 2000; Walby \& Carrier (2010). 